\title{
Proletarian Internationalism, "Soviet Patriotism" and the Rise of Russocentric Etatism During the Stalinist 1930s ${ }^{1}$
}

\section{David Brandenberger}

In 1937, one of the most perceptive critics associated with the Menshevik movement in Parisian exile, Vera Aleksandrova, summarized her misgivings about Moscow's evolving official line in the following way:

\begin{abstract}
The most characteristic aspect of the newly-forming ideology ... is the downgrading of socialist elements within it. This doesn't mean that socialist phraseology has disappeared or is disappearing. Not at all. The majority of all slogans still contain this socialist element, but it no longer carries its previous ideological weight, the socialist element having ceased to play a dynamic role in the new slogans. It is most possible to see these subtle moves in minor but representative examples. At first, one was to speak of the USSR as the "country of the proletarian dictatorship," and then the "motherland of socialism" and the "motherland of toilers of the whole world." During the "socialism in one country" construction period, the USSR was referred to officially as the "socialist fatherland." Toward the end of the First Five-Year Plan, the more intimate [term] "socialist motherland" or "soviet motherland" appeared, while today [the USSR] is referred to over and over again as simply "our motherland." According to our contemporaries' perceptions, "our motherland" sounds warmer, more joyful and less official and bureaucratic than "socialist motherland."
\end{abstract}

Even more heretical, according to Aleksandrova, was the fact that class analysis had been eclipsed by the rehabilitation of non-Marxist analytical categories: "props from the historic past - the people, ethnicity, the motherland, the nation and patriotism - play a large role in the new ideology."2

What was it about Soviet propaganda in the mid-to-late 1930s that had so incensed Aleksandrova? Put most bluntly, she was reacting to no less than an ideological volte-face in which 1917's emphasis on proletarian internationalism had been superseded by a new interest in russocentrism and the Russian historical past. In fact, Soviet propaganda during these years came to display characteristics that commentators like Benedict Anderson, Raphael Samuel, Linda Colley and others typically associate with nationalism and the nation-state, ${ }^{3}$ especially the focus on "the people, the ethnicity, the motherland, the nation and patriotism." This article seeks to trace the process that 
Aleksandrova observed during the 1930s, examining the semantic fluctuation of Soviet interwar sloganeering and the "downgrading of the socialist elements within it." Such an investigation can illustrate how the celebration of Marxist thematics and Soviet patriotism during the early-to-mid 1930s ultimately contributed to the ascendancy of a more russocentric, etatist ideological line late in the decade.

Aleksandrova had good reason to write that the transformation underway in 1937 was essentially an "ideological metamorphosis." After all, a shift to ethnic particularism in the 1930s - especially Russian ethnic particularism would seem utterly incompatible with the party ideology of the 1920s. Over the course of the first fifteen years of Soviet power, M. N. Pokrovskii and other early Soviet historian-ideologists had all tended to vilify russocentrism, painting pre-revolutionary Russian history in exclusively dark colors as the story of a chauvinistic, colonizing nation carrying out the will of an oppressive tsarist system. ${ }^{5}$ They proposed as an alternative a propaganda line based on Marxist-Leninism which foregrounded the study of historical materialism, social forces, class antagonism and economic development on an international scale. As if in reference to the line from the Communist Manifesto that "the workers do not have a fatherland" 6 ideological tracts during the 1920s repeatedly emphasisized the primacy of class analysis. Even after the inauguration of the "Socialism in One Country" thesis in the mid-1920s, Soviet propagandists continued to stress class as a more fundamental and decisive social category than other paradigms drawn along ethnic or national lines. A well-known NEP-era legal commentator epitomized this approach in 1927, declaring: "in our times, patriotism's role is that of an extremely reactionary ideology, the task of which is to justify imperialist bestiality and deaden the proletariat's class consciousness." Summarizing well the prevailing view in the press, the article continued that although it was reasonable for workers to show loyalty to societies organized in their interest, such an emotion had little to do with "national" or "ethnic" affinities. It was, rather, internationalist, proletarian solidarity being at the heart of the emotion and not national borders or blood. ${ }^{7}$ As a result of such thinking, the class-based Soviet allegiance system during the 1920s did not attempt to rally all segments of society together; indeed, non-labouring elements and other tsarist hold-overs were generally considered incapable of loyalty to the workers' state and were even forbidden to bear arms in defense of the USSR. ${ }^{8} \mathrm{~A}$ left-leaning American observer commented at the time that the emerging society was "not handicapped by patriotism" - comparing such beliefs to religiosity, he observed that they were "sentimental idealisms to the materialist Bolsheviks."

But less than five years later, Stalin was starting to call such militancy into question. Acknowledging at a major conference in 1931 that Marx and Engels had been right that "in the past we didn't have and could not have had a 
fatherland," he cautioned against taking such a line of reasoning too far. After all, "now, since we've overthrown capitalism and power belongs to the working class, we have a fatherland and will defend its independence." 10

What was responsible for this about-face? Apparently, the party hierarchy had become frustrated with the previous decade's ineffective ideological line (particularly its materialist and anti-patriotic aspects). ${ }^{11}$ Realizing that such concepts were too arcane and abstract to inspire the USSR's poorly educated population, Stalin and his colleagues began to look for a more pragmatic, populist alternative which would focus on the rather iconoclastic idea of a "socialist fatherland" (to use Aleksandrova's expression). By the mid-1930s, Pravda was promoting precisely such a view without reservation: "Soviet patriotism is a burning feeling of boundless love, a selfless devotion to one's motherland and a profound responsibility for her fate and defense, which issues forth like mighty spring waters from the depths of our people." New sloganeering attempted to rally to the proletarian cause people from outside the industrial working class, ranging from peasants like A. S. Molokova to scholars like Academician A. Bogomolets and the Arctic explorer O. Iu. Shmidt. ${ }^{12}$ In other words, the 1920s' orthodox view of class-based internationalist loyalty had been supplanted by a new notion of patriotic loyalty revolving around the interchangeable concepts of "motherland" and "fatherland" a propaganda line which aspired to unite all segments of the society together for the first time since 1917. G. Vasil'kovskii elaborated on this shift in a prominent article in Pravda in May 1934. Echoing Stalin's 1931 commentary, he argued that although Marx and Engels had been correct in 1848 that "the workers do not have a fatherland," the October 1917 revolution had changed things dramatically by producing a workers' state in the midst of a capitalist encirclement. ${ }^{13}$ In such a situation, patriotic loyalty to the fatherland was not only possible, but desirable. Moreover, official coverage of the issue in the press indicated that social origin and class were no longer to limit one's ability to be a Soviet loyalist: not only could people from outside the ranks of the industrial proletariat like peasants and scholars now genuinely support Soviet power, but even members of the old nobility like Count Aleksei Tolstoi could be welcomed to the cause. ${ }^{14}$ The decisive role of class consciousness in Soviet ideology had given way to a new sense of allegiance based on membership within Soviet society. The entire notion of "Soviet patriotism" would be given a firm theoretical basis by K. B. Radek in $1936,{ }^{15}$ marking the maturation of a major press campaign which expanded the notion of "Soviet" from a partyoriented affinity based on class to a broader understanding which would henceforth encompass geographic and cultural semantics as well. ${ }^{16}$

Populism complemented this departure from class as the sole organizational principle of Soviet society. Such an initiative was launched as early as 1931 by people concerned with propaganda and societal mobilization like A. M. Gor'kii, who contended that heroes could be used to popularize the 


\section{Left History 6.2}

nascent patriotic line "by example." A marked contrast to the 1920s' focus on anonymous social forces and class struggle, this led to the prioritizing of what was essentially a new genre of agitational literature. Prominent multi-volumed series like Gor'kii's History of Plants and Factories and The History of the Civil War in the USSR began to assemble a new pantheon of Soviet heroes, socialist myths and modern-day fables. This "search for a usable past" ${ }^{17}$ not only focused on shock workers in industry and agriculture, but also lavished attention on prominent Old Bolshevik revolutionaries, industrial planners, party leaders, komsomol ${ }^{18}$ officials, comintern activists, Red Army heroes, non-Russians from the republican party organizations and even famous members of the secret police. ${ }^{19}$ Such populist, heroic tales from the recent past were seen as providing a common narrative that the entire society would be able to relate to - a rallying-call with greater social application than the previous decade's narrow and impersonal focus on class and materialism.

Reflecting emergent trends in Socialist Realism ${ }^{20}$ as well as Stalin's belief in the traditionalist notion of "the great men of history," 21 this stress on heroism took center stage at the first conference of the Soviet Writers' Union in $1934 .{ }^{22}$ In the wake of this conference, a massive array of literature was commissioned to develop and expand upon the new Soviet Olympus and its pantheon of contemporary heroes. Films like Counterplan, Chapaev, The Happy Fellows, Circus, The Frontier, Flyers, The Courageous Seven, Miners and Volga-Volga complemented the campaign with celluloid agitation. Epitomizing this type of propaganda is one of the final scenes in G. V. Aleksandrov's film The Radiant Path, a late example of this genre. Mounting a podium at an industrial exhibition, the heroine, an illiterate maid-turnedengineer and Supreme Soviet Deputy, leads her audience in a rousing verse from the film's theme song "The March of the Enthusiasts":

In these days of great construction sites In the merry din, the ringing and the lights, I send my greetings to this country of heroes To this country of scientists, to this country of dreamers! $!^{23}$

Both populist and pragmatic, such films aimed to inspire "by example," mobilizing Soviet citizens of different social origins, professional occupations and ethnicities under the common banner of Soviet patriotic heroism.

But it would be incorrect to think that film was the chief vehicle for this propaganda, as much of the content for the new campaign was supplied by a torrential wave of books and artwork rolling off the presses. Party history texts and glossy picture albums appearing in massive print-runs detailed heroism on the factory floor as well as in construction projects, the non-Russian republics and even such exotic fields as aeronautics and polar exploration. ${ }^{24}$ Heroic Old Bolsheviks (e.g. A. S. Enukidze, Ia. E. Rudzutak), as well as prominent figures from the ranks of industry (lu. L. Piatakov), the party (A. I. Rykov), the 
komsomol (A. V. Kosarev), the comintern (O. A. Piatnitskii), the Red Army (A. I. Egorov), the republican parties (F. Khodzhaev) and the NKVD (Ia. Peters, N. I. Ezhov), received tremendous acclaim and seemed destined to grace the pages of official propaganda tracts for many years to come. As noted above, such books, posters and films were designed to elaborate upon the Soviet "usable past," complementing Socialist Realism's fictional heroes with famous and recognizable personalities from the first fifteen years of Soviet power.

But although this Soviet patriotic populism was expected to supply a unifying narrative that would provide for an upswell of social support for the regime, the campaign faltered within only a few years of its inception. The Great Terror, which tore gaping holes in the fabric of the party hierarchy, the bureaucracy, the military high command, and the intelligentsia between 1936 and 1938, was - by its very nature - unable to leave the new Soviet pantheon of heroes unscathed. As S. V. Zhuravlev explains in his monograph on the multi-volumed History of Plants and Factories book series, the launching of the purges quickly came to wreak havoc with the new propaganda line. For instance,

... work on the book [about the Moscow metro system] was undermined in 1936. Mass repressions, beginning in Metrostroi [the metro construction organization], affected the members of the editorial board under Kosarev as well as the best and most active of the workers, specialists and construction leadership - that is, precisely those people who were supposed to "populate" the fundamental book on the history of the metro ....25

This same phenomenon would be repeated with histories of the party, the Red Army and the komsomol, as successive waves of purging stripped bare the emerging pantheon of heroes and depopulated the narratives under construction. Similar fates befell projects focusing on industrial zones like Magnitogorsk and Moscow's Stalin auto plant. ${ }^{26}$ The infamous 1934 book on the construction of the Belomor Canal had to be hastily withdrawn from circulation late in 1937 when its editorial board and many of its principle characters were arrested. ${ }^{27}$ Dovetailing with the Belomor Canal book was the 1934 Russian-language edition of Uzbekistan at 10 Years. A glossy photo album designed by the famous graphic artist A. M. Rodchenko, it required extensive airbrushing before appearing in Uzbek during the following year when the fall of Avel' Enukidze necessitated his removal from group portraits printed in the volume. ${ }^{28}$ Even in revised form, however, Uzbekistan at 10 Years did not remain in circulation for long due to the widening maw of the party purges. Rodchenko's own copy of the book reveals preparations for a third edition in a particularly gruesome manner: blacked out in India ink are the pictures of prominent party and state functionaries like la. E. Rudzutak and Ia. Peters, as well as luminaries from the Uzbek party organization like $\mathrm{F}$. 
Khodzhaev, A. Ikramov, A. A. Tsekher, D. Abikova, A. Babaev and T. Khodzhaev, all of whom "disappeared" between 1936 and $1938 .{ }^{29}$

While the sagas surrounding the Belomor and Uzbek books are instructive, perhaps nothing was as dramatic as the fiasco surrounding the first volume of the celebrated History of the Civil War in the USSR series. A narrative focusing on the prelude to the revolutionary events of October 1917, this enormous tome required reissuing in 1938 after the pages of its first edition were found to be littered with the names of Old Bolsheviks who had vanished during the on-going purges. Brief consideration of the volume's contents graphically illustrates how the Great Terror compromised the propaganda value of such texts. Of the sixty-eight individuals who are mentioned in a positive light on the pages of the 1935 edition, fifty-eight were given treatment broad enough to be considered truly "heroic." During the first stages of the party purges in 1936, nearly half of the members of this pantheon were arrested, requiring the volume to be withdrawn from circulation. When the second edition appeared in 1938, it had been stripped of numerous pictures, illustrations and some 27 pages of text, not to mention all passing references to fallen heroes like Piatakov, Rykov and Piatnitskii. ${ }^{30}$ The next volume in the series - a 600-page book concerning the single month of October 1917 - did not appear until 1943, the five-year delay apparently stemming from the difficulty involved in drafting a detailed narrative about the revolution without mentioning dozens of individuals now considered enemies of the people. ${ }^{31}$ The third volume in the series would not appear until 1957.

But the purges' fall-out was not limited to commemorative albums and picture books. A. P. Dovzhenko's film Shchors, a civil war epic about a Ukrainian revolutionary commissioned in 1935, had to be reshot after Shchors' right-hand man fell victim to the purges and had to be removed from the screenplay. ${ }^{32}$ Prominent mention of fallen Red Army heroes like A. I. Egorov required excision from public school history texts between 1937 and 1941.33 The release of the seminal Short Course on the History of the All-Union Communist Party (Bolsheviks) was repeatedly postponed as the purges' bloodletting necessitated the removal of numerous names - not only from the narrative, but from the book's editorial board as well. Finally released in the fall of 1938, the Short Course required additional revisions two years later in order to eliminate all mention of N. I. Ezhov, who had been arrested and shot during the intervening period. ${ }^{34}$ Rumors of further purges even endangered the small library of publications revolving around $O$. Iu. Shmidt, the Cheliuskintsy and other hero-explorers of the far north. ${ }^{35}$ Uncertainty on the ground level over what to read (and what to teach) panicked officials and propagandists alike, bringing political agitation efforts in the society to a standstill. ${ }^{36}$ Propaganda revolving around Soviet patriotism was virtually hamstrung by the events of 1936-1938 due to the fact that this campaign had been predicated on the ability to propagandize heroes from the recent past. Unable to even publish 
a tenable biography of Stalin for much of the 1930s due to the purges' effect on the General Secretary's entourage, ${ }^{37}$ the rallying of popular support for the regime "by example" became almost prohibitively difficult. This state of affairs ultimately forced the party hierarchy to resume its now increasingly frantic "search for a usable past" according to an entirely different strategy.

On the eve of the meltdown of the Soviet pantheon of heroes, another campaign - "the Friendship of the Peoples" - was maturing under the same patriotic rubric. Designed to aid in the mobilization of the diverse Soviet nations, it had been inaugurated by Stalin in December $1935^{38}$ and revolved around the interethnic cooperation and racial harmony purportedly made possible by socialism. ${ }^{39}$ That being said, it also contained another dimension that had first surfaced (interestingly enough) in the 1934 article by Vasil'kovskii referred to above: the valorization of the Russian proletariat "who gave the world the October revolution." Taboo since 1917, this Russian ethnic particularism was supported by references to a then little-known fragment of Leniniana entitled "On the National Pride of the Great Russians." An integral, if not officially-acknowledged element of the "Friendship of the Peoples" campaign, this russocentric undercurrent resurfaced again in a Pravda editorial in early 1936:

\begin{abstract}
All the peoples - participants in the great socialist construction - may be proud of the results of their labour; every one of them - from the smallest to the largest - are Soviet patriots enjoying a full array of rights. First among these equals is the Russian people, the Russian workers and the Russian toilers, whose role throughout the whole Great Proletarian Revolution, from the first victories to the present day's brilliant period of development, is exceptionally large.
\end{abstract}

Why was this russocentrism such a central component of the "Friendship of the Peoples" sloganeering? Apparently, the purges' paralysis of campaigns revolving around individual Soviet heroes had left few alternatives to the rehabilitation of an ethnically-organized "usable past." Stalin's praise of the dexterous "revolutionary Russian sweep-of-the-hand" repeated several times in the text of the editorial, was not accidentally juxtaposed against the underdevelopment of the non-Russian Soviet peoples. In the wake of this article, the parenthetical expression "first among equals" would be used with increasing frequency in reference to the Russian people's place in Soviet society, ${ }^{41}$ foreshadowing the later emergence of an explicit ethnic hierarchy.

Although the press initially limited its Russian ethnic particularism to contributions during the revolution, with time, Civil War victories ${ }^{42}$ and the Stakhanovite movement also assumed Russian characteristics. ${ }^{43}$ Then, in January 1937, this cultural sphere of influence was expanded beyond the parameters of the Soviet experience itself, when the figurehead President of the USSR, M. I. Kalinin, proclaimed at a major conference that: 
The Russian people have drawn out of their midst no few people who, by means of their talent, have raised the world's cultural level Lomonosov, Pushkin, Belinskii, Dobroliubov, Chernyshevskii, Nekrasov, Shchedrin, Chekhov, Tolstoi, Gor'kii, Surikov, Repin, Glinka, Tchaikovsky, Rimskii-Korsakov, Mendeleev, Timiriazev, Pavlov, Michurin, Tsiolkovskii .... All of this speaks to the Russian people's role in the development of world culture. ${ }^{44}$

Triumphant recognition of such an array of cultural figures from the ancien régime - and their specific identification as ethnic Russians - signaled the scope and direction of the new line. The transformation of A. S. Pushkin into an icon of official Soviet literature during January and February of 1937 catalyzed this revival of prominent names and heroes from the prerevolutionary Russian past. Tsarist-era political and military figures like Aleksandr Nevskii, Peter the Great, Aleksandr Suvorov and Mikhail Kutuzov were even rehabilitated later that fall. ${ }^{45}$ Shortly thereafter, Bol'shevik, the party's main theoretical journal, would wax rhapsodic that "the history of the Russian people is the history of their heroic fight for independence and freedom against numerous enemies, conquerors and interventionists." 46 Placing the Russians at the head of the multiethnic Soviet family of peoples, the Minor Soviet Encyclopedia would argue on the eve of the War that "the culture of the USSR's peoples is historically tied to the culture of the Russian people. It has always experienced and will continue to experience the benevolent influence of the advanced Russian culture." ${ }^{27}$ Unmistakable here is a shift in emphasis in Soviet ideology from the workers as the vanguard class of the Soviet experiment to the Russian people as its vanguard nation. ${ }^{48}$ Russocentrism and the celebration of the Russian historical past would form an important part of official propaganda campaigns until after Stalin's death in 1953.

But why such an about face from proletarian internationalism to nationalism? What can explain such heresy? As alluded to above, a pragmatic and urgent need for mobilization predicated this sea-change in party ideology. By the early 1930s, the propaganda of the previous decade was increasingly seen as being excessively abstract, inaccessibly arcane and insufficiently populist. Importantly, the new campaigns surrounding Soviet-era heroes were quickly complemented by the revival of historical personalities from the national past. Instructive is one of the first major challenges to the historical materialist line of the 1920s which occurred during a Politburo discussion of public school history textbooks in March 1934. Objecting to the presentations of several distinguished Bolshevik pedagogues, Stalin launched into a vicious critique of their advocacy of textbooks that privileged materialism and class analysis over a more traditional historical narrative. ${ }^{49} \mathrm{~A}$ leading ideologist present at the meeting paraphrased Stalin's remarks several days later: 


\begin{abstract}
These textbooks and the instruction [of history] itself is far from what is needed, and Comrade Stalin talked about this at the Politburo meeting. The textbooks and the instruction [of history in the schools] itself is done in such a way that sociology is substituted for history .... What generally results is some kind of odd scenario [neponiatmaia kartina] for Marxists - a sort of bashful relationship - [in which] they attempt not to mention tsars and attempt not to mention prominent representatives of the bourgeoisie .... We cannot write history in this way! Peter was Peter, Catherine was Catherine. They relied on specific classes and represented their mood and interests, but all the same they took action - these were historic individuals - they were not ours, but we must give an impression of this epoch, about the events which took place at that time, who ruled, what sort of a government there was, what sort of policies were carried out, and how events transpired. Without this, we won't have any sort of civil history. 50
\end{abstract}

Stalin's commentary was understood by insiders as a call for the revival of conventional state- and personality-based narratives in historically-oriented propaganda. A. S. Bubnov, the Commissar of Education, followed up on Stalin's prescriptions at a historians' conference later that month. Focusing on the excessively schematic (or "sociological") approach to history reflected in the historiography of the $1920 \mathrm{~s}$, Bubnov complained that theory was dominating the discussion of history in the schools, leaving events, personalities, and their interconnection to play only a secondary role. As a result, he noted "an entire array of the most important historical figures, events, wars, etc. slips past [our students] unnoticed.... Under such conditions, we have a very large over-encumbrance of what can be referred to as the sociological component, and a major lack, even a complete absence in some places, of what can be referred to as pragmatic history."51 Such calls for "pragmatic history" (or "a usable past") echoed throughout such forums during the mid-1930s. Synchronized with the above-mentioned explosion of patriotic rhetoric in the press, "pragmatic history" was to catch people's imaginations and promote a unified sense of identity that the previous decade's materialism had failed to stimulate.

Aside from the changes in tone and content, however, we see in Stalin's recommendations something else as well: the endorsement of what was essentially an etatist interpretation of the pre-revolutionary history of the USSR. Such redirection of historiographic priorities to highlight statehood particularly Russian statehood - is significant, as we see here the outline of an agenda to replace the 1920s' broad "multicultural" materialist focus on the history of classes and peoples with a single, linear, nation-based narrative. ${ }^{52}$ Such an impression is confirmed by an account of another Politburo discussion from March 1934 in which Bubnov proposed that the official historical line ought to concern not just the linear pre-revolutionary "history of the USSR," 


\section{Left History 6.2}

but a broader and more inclusive "history of the peoples of Russia." Interrupting him, Stalin disagreed, implying that such a focus was excessively diffuse. Asserting that a single thousand-year political narrative ought to be at the center of the new curriculum, he noted simplistically that "the Russian people in the past gathered the other peoples together and have begun that sort of gathering again now." 53 Although terse, Stalin was visibly rejecting a multicultural history of the region in favor of a historical narrative which would implicitly focus on the Russian people's state-building across time. When the next generation of history textbooks rolled off the presses in 1937, they dovetailed perfectly with this vision of the "usable past," 54 as did some of the biggest films of the day which also valorized pre-revolutionary princes, monarchs and generals, e.g. Peter the First, Aleksandr Nevskii, Minin and Pozharskii, Suvorov, etc. ${ }^{55}$ The same idea also reverberates throughout a toast that Stalin gave at K. E. Voroshilov's dacha after reviewing the Red Square parade commemorating the twentieth anniversary of the revolution in 1937:

\footnotetext{
I want to say a few words which may not seem too festive. The Russian tsars did much that was bad. They robbed and enslaved the people. They led wars and seized territory in the interests of the landowners. But they did do one good thing - they put together an enormous state [stretching] out to Kamchatka. We inherited this state. We Bolsheviks were the first to put together and strengthen this state not in the interests of the landowners and capitalists, but for the toilers and for all the great peoples who make up this state. ${ }^{56}$
}

Etatist sympathies, then, in conjunction with a strong current of populism and frustration with the purges' paralysis of propaganda revolving around Soviet heroes, led the party hierarchy to conclude that the most effective historical narrative for the diverse Soviet population would be a Russian-centered one stressing old-fashioned values like state-building and national defense ${ }^{57}$ Late in the decade, Stalin would even call for adjustments to be made to the official conceptualization of "Soviet patriotism" in order to account for the shift. ${ }^{58} \mathrm{M}$. I. Kalinin responded to Stalin's calls to "develop and cultivate" the concept in 1940 with the announcement that "Soviet patriotism" at its core was a sense of pride and loyalty which had united both Russians and the "most conscious elements of the oppressed nationalities" under the progressive banner of Russian "national culture" since the mid-nineteenth century. ${ }^{59}$ Such a russocentric vision was the end result of the "ideological metamorphosis" that Aleksandrova had identified in 1937. In the words of another exile writing at about the same time, Soviet patriotism during the second half of the 1930s had become "simply Russian patriotism."60

It should come as no surprise that some in the Soviet society of the 1930s were horrified by this ideological turn-about. In early 1939, a veteran leftist 
literary critic named V. I. Blium even had the audacity to complain directly to Stalin in a personal letter about how "socialist patriotism sometimes and in some places is starting to display all the characteristics of racial nationalism." But the party hierarchy remained committed to the new line, ${ }^{61}$ even amplifying it somewhat between 1941 and 1945. Little else of substance changed until the mid-1950s.

This article has traced the changing semantics of Soviet mobilizational ideology during the 1930s, focusing on the wane of internationalism, the emergence of Soviet patriotism and the remodulation of this concept away from a focus on a Soviet heroic Olympus toward a pantheon of heroes drawn chiefly from the pre-revolutionary Russian historical past. This shift toward russocentrism in interwar Soviet ideology has long been a source of scholarly controversy. Some have linked this phenomenon to nationalist sympathies within the party hierarchy, ${ }^{62}$ while others have attributed it to eroding prospects for world revolution, ${ }^{63}$ and the Stalinist elite's revision of Marxist principles. ${ }^{64}$ Others associate the transformation with increasing threats from the outside world, ${ }^{65}$ domestic etatism ${ }^{66}$ and administrative pragmatism. ${ }^{67}$ Still others contend that the phenomenon really only matured in the $1940 \mathrm{~s}$ in connection with the exigencies of the German invasion. ${ }^{68} \mathrm{~A}$ few even deny that it occurred at all. ${ }^{69}$ With A. M. Dubrovskii, I have argued elsewhere that russocentric themes were privileged in Soviet ideology during the late 1930s within the context of the decade's etatist tendencies. The evolution of the official historical line during these years indicates that the era's reliance on the Russian national past, heroes and myths was a nativist move to popularize a single historical narrative on the pre-revolutionary era for the USSR's poorly-educated citizenry. Put another way, a new sense of pragmatism came to the fore in the party hierarchy of the 1930s which concluded that the utopian proletarian internationalism that had typified Soviet ideology during its first fifteen years was inhibiting the mobilization of Soviet society for industrialization and war. Searching for a more populist rallying call, Stalin and his inner circle eventually settled upon russocentric etatism as the most efficient way to promote statebuilding and popular loyalty to the regime. ${ }^{70}$

But critical to this story is the thesis advanced in the present article: that much of the primacy of the era's emphasis on russocentrism and prerevolutionary glory ought to be seen as a syndrome of the purges' hamstringing of parallel propaganda campaigns revolving around "Soviet patriotism" and the heroes of the revolution and socialist construction. Because the party hierarchs' interest in the tsarist past was so instrumental, they seem to have expected, ca. 1935, that themes, imagery and other elements drawn from the "pragmatic history" of the pre-revolutionary time period could co-exist with other more "Soviet" aspects of the official propaganda line. The USSR's Olympus was to be 


\section{Left History 6.2}

an integrated one, with Peter the Great, Aleksandr Nevskii and A. S. Pushkin joining Chapaev, Dzerzhinskii, Frunze, Shchors, Enukidze, Rykov, Kosarev, Khodzhaev, Egorov and numerous Stakhanovites in a heroic pantheon styled according to the reigning aesthetics of Socialist Realism.

However, as manic purging in the mid-to-late 1930s destabilized industry, the Red Army command, and the party itself, many Soviet members of the party's nascent pantheon of heroes were swept into the deluge as well. Mobilization "by example" was greatly complicated by the sudden arrest or disappearance of celebrated workers, managers, party officials and military commanders, something which in the short term required the reissuing of many canonical propaganda texts and in the long term threatened to compromise the entire pantheon itself. At times, it must have seemed as if only Socialist Realism's fictional heroes - Pavel Korchagin, Gleb Chumalov and others did not risk arrest. ${ }^{71}$

If the new line's emphasis on russocentric themes and leaders from the tsarist past had been initially off-set (or even over-shadowed) by the popularization of Soviet heroes from the civil war era and on-going socialist construction, the purges' destruction of many of these prominent personalities between 1936 and 1938 complicated this genre of propaganda and contributed to a shift toward an increasing emphasis on heroes from the distant past. Attrition within the ranks of the "Soviet patriots" (Enukidze, Rykov, Kosarev, Khodzhaev, Egorov, etc.) left the pantheon composed principally of traditional Russian national heroes (Nevskii, Peter, Pushkin) and a handful of remaining revolutionaries (Lenin, Stalin, Frunze, Dzerzhinskii, Shchors, etc.). Consequently, increased reliance on traditional Russian heroes was virtually inevitable: not only were the Peters and Nevskiis at least as recognizable as the Frunzes and Shchors', but they were also often more heroic (at least according to traditional aesthetics) and less likely to be compromised by the purges. ${ }^{72}$ In this sense, the faltering of the Soviet patriotism campaign during the Great Terror contributed to the ascendancy of a russocentric vision of the USSR's "usable past" which would prove to be durable and dynamic enough to script Soviet propaganda campaigns over the course of the next twenty years.

\footnotetext{
1 Research for this article was supported in part by a grant from the International Research \& Exchanges Board (IREX), with funds provided by the National Endowment for the Humanities and the United States Department of State, which administers the Russian, Eurasian, and East European Research Program (Title VIII). An earlier version of this article was discussed at Indiana University's "Inventing the Soviet Union" Conference. This article likewise benefited from communications with Jeffrey Rossman, Katia Dianina, Eric Lohr, A. M. Dubrovskii, Terry Martin, Kari Bronaugh and two anonymous reviewers for Left History. Conclusions and errors contained herein remain the sole responsibility of the author.
} 
2 The last line in Russian reads: "Bol'shuiu rol' $v$ novoi ideologii igraiut rekvizity istoricheskogo proshlogo: narod, narodnost', rodina, natsiia, patriotizm." $\mathrm{V}$. Aleksandrova, "Ideologicheskie metamorfozy," Sotsialisticheskii vestnik, 27 April 1937, 14. An early study of this phenomenon is S. Maksudov's "Edinozhdy solgavshi, kto tebe poverit: Opyt sravnitel'nogo lozungovedeniia," Strana i mir no. 11 (1991), esp. 37-9.

${ }^{3}$ Benedict Anderson, Imagined Communities: Reflections on the Origin and Spread of Nationalism, revised edition (New York 1993), passim, esp. 11, 109-110; Raphael Samuel, "Continuous National History," in Patriotism: the Making and Unmaking of British National Identity (New York 1989), 9-17; Linda Colley, Britons: Forging the Nation, 1707-1837 (New Haven 1992), 167-68, 178-82, etc.

4 A historian who taught at Kiev State University in the 1930s made the same point about the shift from Soviet patriotism to "Russian great power nationalism" in his postwar memoirs. See Konstantin Shteppa, Russian Historians and the Soviet State (New Brunswick, N.J. 1962), 136, 134.

5 Roman Szporluk, "History and Russian Ethnocentrism," in Ethnic Russia in the USSR: the Dilemma of Dominance, Edward Allworth, ed. (New York 1980), 42.

${ }^{6}$ See the academic edition printed in a split-face German-Russian format: K. Marks [Marx] and F. Engels, Manifest kommunisticheskoi partii (Moscow 1937), 108-9.

${ }^{7}$ Entsiklopediia gosudarstva i prava, vol. 3 (Moscow 1927), s.v. "Patriotizm," by P. Stuchka, 252-54; See also Malaia Sovetskaia entsiklopediia, vol. 6 (Moscow 1931), s.v. "Patriotizm," by M. Vol'fson, 355-56.

8 See the resolutions of the fifth and twelfth All-Russian Congresses of Soviets, reprinted in S"ezdy sovetov RSFSR $v$ postanovleniiakh $i$ rezoliutsiiakh, A. Ia. Vyshinskii, ed. (Moscow 1939), 90, 94, 306; S. A. Krasil'nikov, "Tyloopolchentsy," Ekho no. 3 (1994), 176-177.

${ }^{9}$ Samuel Harper, Making Bolsheviks (New York 1931), 18.

10 Italics added. I. V. Stalin, "O zadachakh khoziaistvennikov: rech' na pervoi Vsesoiuznoi konferentsii rabotnikov sotsialisticheskoi promyshlennosti, 4-go fevralia 1931," in Voprosy Leninizma (Moscow 1934), 445.

11 See chapter one of my thesis "The 'Short Course' to Modernity: Stalinist History Textbooks, Mass Culture and the Formation of Popular Russian National Identity, 19341956," Ph.D. thesis, Harvard University, 1999.

12 "Sovetskii patriotizm," Pravda, 19 March 1935, 1; A. S. Molokova, "I ia govoriu synam: zashchishchaite nashu stranu," ibid., 18 June 1934, 2; A. Bogomolets, "Pochva, kotoraia rozhdaet geroev," ibid, 3; "Za rodinu," ibid., 9 June 1934, 1. See also "Mozhno zavidovat' strane, imeiushchei takikh geroev, i geroiam, imeiushchim takuiu rodinu," ibid., 19 June 1934, 2. Further evidence of the transformation underway is supplied by the fact that the term for those deemed hostile to the Soviet cause shifted during this time from "class enemy" [klassovyi vrag] to "enemy of the people" [vrag naroda].

13 G. Vasil'kovskii, "Vysshii zakon zhizni," Pravda, 28 May 1934, 4. Exiled Mensheviks received news of the mid-1930s' ideological shift with surprise. See " $\mathrm{Za}$ rodinu," Sotsialisticheskii vestnik, 25 June 1934, 1-2; "Propavshii lozung," ibid., 10 May 1936, 1-2.

14 “Rech' tov. V. M. Molotova o novoi konstitutsii," Pravda, 30 November 1936, 2, reprinted in V. M. Molotov, Stat 'i i rechi, 1935-1936 (Moscow 1937), 225.

${ }^{15}$ K. Radek, "Sovetskii patriotizm," Pravda, 1 May 1936, 6. See also idem, "Moia 
rodina," Izvestiia, 6 July 1934, 2. On the articulation of Soviet patriotism, see "Kniga o sotsialisticheskoi rodine [review]," Sputnik agitatora no. 19-20 (1937), 73-6; K. Sokolov, "Sovetskic patrioty," ibid. no. 3 (1938), 13-14; idem, "My - sovetskic patrioty," ibid. no. 14-16 (1938), 14-16; E. Sitovskii, "O sovetskom patriotizme," Pod znamenem marksizma no. 9 (1939), 39-57; "Patriot" and "Patriotizm," in Tolkovyi slovar' russkogo iazyka, B. M. Volin and D. N. Ushakov, eds., vol. 3 (Moscow 1939), 68; Vasetskii, "Moral'no-politicheskoe edinstvo sovetskogo obshchestva," Bol'shevik no. 13 (1940), 35-46; M. Kammari, "O proletarskom internatsionalizme i sovetskom patriotizme," ibid. no. 15-16 (1940), 28-42; "Patriotizm," in Politicheskii slovar', G. Aleksandrov, V. Gal'ianov and N. Rubinshtein, eds. (Moscow 1940), 410.

16 While patriotic appeals had been used in party conferences and similar forums, 1934 marks the expansion of the use of this rhetoric in public. See "O rodine," Pravda, 7 August 1934, 4, and other similar articles designed for mass readership.

17 This phrase stems from a famous 1965 essay reprinted in Henry Steele Commager, The Search for a Usable Past and Other Essays in Historiography (New York 1967),

3-27.

${ }^{18}$ The communist youth league.

${ }^{19}$ S. V. Zhuravlev, Fenomen "Istorii fabrik i zavodov" (Moscow 1997), 4-5, 153-4, 1801. Also note A. M. Gor'kii $i$ sozdanie "Istorii fabrik $i$ zavodov" (Moscow 1959), 3-12; A. V. Mitrofanova, I. P. Ostapenko, L. S. Rogachevskaia, "Itogi i perspektivy izucheniia istorii predpriiatii SSSR," in Rabochii klass strany Sovetov (Minsk 1980), esp. 365-6; and "Dorogoi Iosif Vissarionovich! (from Gor'kii)" (27 November 1929), reprinted in Izvestiia TsK KPSS no. 3 (1989), 186. Vera Aleksandrova noticed the new socialist pantheon's role in popularizing the revolution in her "Geroi nashego vremeni," Sotsialisticheskii vestnik, 10 October 1931, 8-11.

${ }^{20}$ On the emergence of the hero in Socialist Realism, see Katerina Clark, The Soviet Novel: History as Ritual (Chicago 1980), 34-5, 72, 119, 136-55, 148, 8-10; idem, "Little Heroes and Big Deeds: Literature Responds to the First Five-Year Plan," in Cultural Revolution in Russia, 1928-1931, Sheila Fitzpatrick, ed. (Bloomington 1978), 205-6. Clark treats the issue slightly differently in her Petersburg: Crucible of the Cultural Revolution (Cambridge 1995), chapter 12 and epilogue, esp. 265-6, 278-9, 288.

21 Although there was little room for individual actors in the classic Marxist understanding of historical materialism, in 1931 Stalin identified a prominent role for decisive leaders aware of the possibilities and limitations of their historical contexts. See "Beseda s nemetskim pisatelem Emilem Liudvigom," Bol'shevik no. 8 (1932), 33. The idea is more fully developed in I. Merzon, "Kak pokazyvat' istoricheskikh deiatelei v shkol'nom prepodavanii istorii," Bor'ba klassov no. 5 (1935), 53-59; Istoriia Vsesoiuznoi kommunisticheskoi partii (bol'shevikov): Kratkii kurs (Moscow 1938), 16; L. Il'ichev, "O roli lichnosti v istorii," Pravda, 27 November 1938, 2. Stalin's view is reminiscent of Hegel's (see G. Hegel, The Philosophy of History, trans. J. Sibree [New York 1956], 30) and dovetailed with emerging trends in Socialist Realism.

22 A. M. Gor'kii and A. N. Tolstoi led the new interest in heroes, which was confirmed by A. A. Zhdanov. See Pervyi vsesoiuznyi s"ezd sovetskikh pisatelei, 1934: Stenograficheskii otchet (Moscow 1934), 8, 17, 417-19, 4. Vera Aleksandrova noticed this phenomenon in emigration with surprise, as evinced by her article "Individualy," Sotsialisticheskii vestnik, 10 January 1934, 10-11, as did Klaus Mehnert in his 
Weltrevolution durch Weltgeschichte: die geschichtslehre des Stalinismus (KitzingenMain 1950), 45, 57-9. Note also V. P. Stavskii's mention of this subject in his diary, excerpted in Intimacy and Terror: Soviet Diaries of the 1930s, Veronique Garros, Natalia Korenevskaya and Thomas Lahusen, eds. (New York 1995), 225.

${ }^{23}$ A loose translation of "V budniakh velikikh stroek, / V veselom grokhote, $v$ ogniakh i zvonakh, / Zdravstvui, strana geroev, / Strana mechtatelei, strana uchenykh!" On the genre's films, see Vstrechnyi (F. Ermler and S. Iutkevich, 1932), Chapaev (the Vasil'ev "brothers," 1934), Veselye rebiata (G. V. Aleksandrov, 1934), Tsirk (Aleksandrov, 1935), Letchiki (Iu. Raizman, 1935), Granitsa (M. Dubson, 1935), Semero smelykh (S. Gerasimov, 1935), Shakhtery (Iutkevich, 1937), Volga-Volga (Aleksandrov, 1938), and Svetlyi put" (Aleksandrov, 1940). See Richard Taylor, "Red Stars, Positive Heroes and Personality Cults," in Stalinism and Soviet Cinema, Richard Taylor and Derek Spring, eds. (London 1993), 69-89.

${ }^{24}$ The best contemporary treatments of Stakhanovite iconography are Clark, The Soviet Novel, passim; Lewis H. Siegelbaum, Stakhanovism and the Politics of Productivity, 1935-1941 (Cambridge 1988), 223-46; and Victoria E. Bonnell, "The Iconography of the Worker in Soviet Art," in Making Workers Soviet: Power, Class and Identity, Lewis H. Siegelbaum and Ronald Grigor Suny, eds. (Ithaca 1994), 362-4, 373-5. See also John McCannon's fascinating account of the campaign surrounding the conquering of the far north in his Red Arctic: Polar Exploration and the Myth of the North in the Soviet Union, 1932-1939 (Oxford 1998).

25 Zhuravlev, Fenomen "Istorii fabrik $i$ zavodov"' 113; See also 73-77, 154. The dimensions of arrests among Stakhanovites require quantification: Lewis Siegelbaum, for instance, contends that few were ever purged in his Stakhanovism and the Politics of Productivity, 225.

26 Stephen Kotkin, Magnetic Mountain: Stalinism as a Civilization (Berkeley 1995), 372; Kenneth M. Straus, Factory and Community in Stalin's Russia (Pittsburgh 1997), 332.

27 Cynthia Ruder, Making History for Stalin: the Story of the Belomor Canal (Gainsville 1998), 88-9, 207, 43. Generally, see Belomorsko-Baltiiskii kanal imeni Stalina: istoriia stroitel'stva, M. Gor'kii, L. Averbakh et al, eds. (Moscow 1934).

${ }^{28}$ See the juxtaposition of photographs from the two editions of 10 let Uzbekistana presented in David King, The Commissar Vanishes: the Falsification of Photographs and Art in Stalin's Russia (New York 1997), 136-37.

29 The relevant pages from Rodchenko's copies of both editions of the volume are reproduced in ibid., 126-33, 136-37.

${ }^{30}$ Twenty-six were recast as traitors or purged from the narrative entirely: la. A. Berzin, A. A. Bitsenko, G. I. Bokii, M. P. Bronskii, N. P. Briukhanov, A. S. Bubnov, N. I. Bukharin, Iu. P. Gaven, P. F. Kodetskii, A. L. Kolegaev, S. V. Kossior, N. N. Krestinskii, G. I. Lomov (Oppokov), V. I. Miliutin, N. Osinskii (V. V. Obolenskii), A. N. Paderin, Ia. Ia. Peche, N. A. Pozharov, G. L. Piatakov, O. A. Piatnitskii, F. F. Raskol'nikov, A. I. Rykov, I. T. Smigla, G. Ia. Sokol'nikov, G. F. Fedorov and K. K. Iurenev.

31 Istoriia grazhdanskoi voiny $v$ SSSR, vol. 2, Velikaia proletarskaia revoliutsiia (Moscow 1943).

${ }^{32}$ For more on the purges' hamstringing of Shchors, commissioned at the height of the "Soviet patriotism" campaign but released only in 1939, see George Liber, “(Re)Creating Shchors," unpublished m.s., 1999. 


\section{Left History 6.2}

33 Compare page 178 of the 1937 edition of Kratkii kurs istorii SSSR, edited by A. V. Shestakov, with the same page in the 1941 edition.

34 Generally, see Appendix C to "The 'Short Course' to Modernity." On the removal of Ezhov's name from pages 197, 234 and 313 of the 1938 edition of Istoriia Vsesoiuznoi kommunisticheskoi partii (Bolsheviks). See "Tovarishchu I. V. Stalinu (from Aleksandrov)" (7 November 1940), Rossiiskii tsentr khraneniia i izucheniia dokumentov noveishei istorii (hereafter RTsKhIDNI), f. 17, op. 125, d. 10, 1. 111. The author is grateful to Peter Blitstein for this reference.

35 On the purges' chilling effect on those involved with arctic exploration, see McCannon, Red Arctic: Polar Exploration and the Myth of the North in the Soviet Union, 149-68.

36 For instance, in late 1937 or early 1938, I. Sorokin, the city procurator of Magnitogorsk, alerted the city's party organization to the fact that local libraries were lending out copies of the History of the Civil War in the USSR which contained portraits of traitors including Bukharin, Zinov'ev and "even Trotsky." See Kotkin, Magnetic Mountain: Stalinism as a Civilization, 583-4.

${ }^{37}$ See D. L. Brandenberger, "Sostavlenie i publikatsiia ofitsial'noi biografii vozhdia katekhizisa stalinizma," Voprosy istorii no. 12 (1997), 141-50.

38 "Rech' tov. Stalina na soveshchanii peredovykh kolkhoznikov i kolkhoznits Tadzhikistana i Turkmenistána," Pravda, 5 December 1935, 3. Parts of this speech remind the reader of the colonial syndrome identified by Edward Said in Orientalism (New York 1978).

${ }^{39}$ Terry Martin, “An Affirmative Action Empire: Ethnicity and the Soviet State, 19231938," Ph.D. thesis, University of Chicago, 1995, 919-81.

40 Vasil'kovskii, "Vysshii zakon zhizni," 4; V. I. Lenin, "O natsional'noi gordosti velikorossov," reprinted in his Sochineniia, vol. 18 (Moscow 1936), 80-83, esp. 81. Stalin associated 1917 specifically with the Russian working class in his 1923 essay " $\mathrm{K}$ voprosu o strategii i taktike russkikh kommunistov," reprinted in his Sochineniia, vol. 5 (Moscow 1952), 178-180.

41 "RSFSR," Pravda, 1 February 1936, 1. The article obliquely quoted Stalin's 1924 essay "Ob osnovakh leninizma," reprinted in Sochineniia, 6: 186-88.

${ }^{42}$ See the draft by A. I. Stetskii and N. L. Rubinshtein to L. Z. Mekhlis commemorating the twentieth anniversary of the Red Army: "At the front during the Civil War, the sons of the Russian people - the first among equals - shoulder to shoulder with Ukrainians, Belorussians, Georgians, Uzbeks and toilers of the other peoples of our country defeated the White Guardists and interventionists." "K dvadtsatiletiiu RabocheKrest'ianskoi Krasnoi Armii i Voenno-morskogo flota," Rossiiskii gosudarstvennyi voennyi arkhiv (hereafter RGVA), f. 9, op. 29s, d. 355, 11. 126, 163.

43 "RSFSR," 1.

44 M. N. Kalinin, "O proekte konstitutsii RSFSR: nasha prekrasnaia rodina," Pravda, 16 January 1937, 2. See also "Velikii russkii narod," ibid., 15 January 1937, 1; "Konstitutsiia geroicheskogo naroda," ibid., 16 January 1937, 1.

45 Synchronized with the revival of tsarist-era political history was the suppression of leftist holdovers who had criticized or satirized the old regime in historiography (the Pokrovskii school), the arts (Dem'ian Bednyi), etc. See "The 'Short Course' to Modernity," chapters three, five and six; A. M. Dubrovskii, "Kak Dem'ian Bednyi ideologicheskuiu oshibku sovershil," in Otechestvennaia kul 'tura i istoricheskaia nauka 
XVIII-XX vekov: sbornik statei (Briansk 1996), 143-51; Kevin Platt and David Brandenberger, "Terribly Romantic, Terribly Progressive or Terribly Tragic? Rehabilitating Ivan IV Under I.V. Stalin, 1937-1953," Russian Review vol. 58, no. 4 (1999), 635-54.

46 B. Volin, "Velikii russkii narod," Bol'shevik no. 9 (1938), 26-37, cite on 28. See also A. Kazakov, "Iz istorii nashei rodiny: 'Ledovoe poboishche,"' Pravda, 27 August 1937, 4.

47 Malaia Sovetskaia entsiklopediia, vol. 9 (Moscow 1941), s.v. "Russkie," by B. Volin, 319-26, cite on 326.

48 This is a paraphrase of Sheila Fitzpatrick's memorable statement on the shift at the University of Chicago's "Empire and Nation in the Soviet Union" Conference, October $26,1997$.

49 This "schematic" view of history, in decline since early in the decade, was thoroughly renounced during M. N. Pokrovskii's posthumous denunciation in January 1936. See my "Who Killed Pokrovskii? (the second time), the Prelude to the Denunciation of the Father of Soviet Marxist Historiography, January 1936," Revolutionary Russia vol. 11, no. 1 (1998), 67-73.

50 "Stenogramma zasedaniia Prezidiuma Komakademii o zadachakh nauchnoi issledovatel'skoi raboty $\mathrm{v}$ oblasti izucheniia istorii $\mathrm{i}$ o rabote nad izdaniem 'Istorii SSSR"' (13 March 1934), Arkhiv Rossiiskoi Akademii Nauk (hereafter Arkhiv RAN), f. 350 , op. 1, d. 906, 11. 1-3ob. See also A. M. Dubrovskii and D. L. Brandenberger, “"Grazhdanskoi istorii u nas net' (ob odnom vystuplenii I. V. Stalina vesnoi 1934 goda," in Problemy otechestvennoi i vsemirnoi istorii (Briansk 1998), 96-100.

51 "Stenogramma soveshchaniia istorikov i geografov pri Narkome tov. Bubnove A. S." (8 March 1934), Gosudarstvennyi arkhiv Rossiiskoi federatsii (formerly known as TsGA, hereafter GARF), f. 2306, op. 69, d. 2177, 1l. 1-2, 3.

52 According to S. A. Piontkovskii, Stalin attacked the same feature of the textbooks two weeks later at a Politburo meeting, cursing that "These textbooks aren't good for anything [nikuda ne godiatsia] .... What[', he] said, [']the heck is 'the feudal epoch,' 'the epoch of industrial capitalism,' 'the epoch of formations' - it's all epochs and no facts, no events, no people, no concrete information, not a name, not a title, and not even any content itself. It isn't any good for anything.['] Stalin repeated several times that the texts weren't good for anything. Stalin said that what we need are textbooks with facts, events and names. History must be history." The diary of Piontkovskii, which is held in the inaccessible archives of the former NKVD (TsA FSB RF, d. R8214), is excerpted in Aleksei Litvin, Bez prava na mysl': istorik v epokhu Bol'shogo terrora - ocherk sudeb (Kazan 1994), 55-57.

53 Ibid., 56. Stalin's comment on the Russian people's historic consolidation of nonRussian minorities during the tsarist era echoes a similar statement in his famous 1913 essay on the national question. Striking is his expansion of the analysis in 1934 to identify a leading role for Russians in Soviet construction. See "Marksizm i natsional'nyi vopros," reprinted in Sochineniia, 2: 304.

54 See "The 'Short Course' to Modernity," chapter three.

55 Petr Pervyi (V. Petrov, 1937, 1939), Aleksandr Nevskii (S. Eisenstein, 1938), Minin $i$ Pozharskii (V. Pudovkin, 1939), Suvorov (Pudovkin, M. Doller, 1941).

${ }^{56}$ Stalin's toast is recorded in the diary of G. M. Dimitrov. See A. Latyshev, "Kak Stalin Engel'sa svergal," Rossiiskaia gazeta, 22 December 1992, 4. According to an account 


\section{Left History 6.2}

of K. E. Voroshilov's adjutant, R. P. Khmel'nitskii, this scene repeated itself the following day in the Kremlin in a more elaborate form. There, Stalin noted that "Old Russia has been transformed into today's USSR where all peoples are identical .... Among the equal nations, states and countries of the USSR, the most Soviet and the most revolutionary is the Russian nation." Robert C. Tucker published an English translation of this speech in his Stalin in Power: The Revolution from Above, 1928 1941 (New York 1990), 482-85, 660. The author is grateful for the latter's willingness to share the original Russian transcript.

${ }^{57}$ For a related discussion, see G. D. Burdei, Istorik $i$ voina, 1941-1945 (Saratov 1991), 170.

58 "Doklad tov. Stalina," in XVIII s"ezd Vsesoiuznoi kommunisticheskoi partil(b), 10-21 marta 1939: Stenograficheskii otchet (Moscow 1939), 26-7. A year later, Stalin added that steps should be taken to tone down "the cult of the civil war." Propaganda surrounding the 1918-1921 time period was apparently precluding a more promising line revolving around imperial military traditions. Stalin had apparently first attacked hagiography revolving around the civil war in late March 1940 at a Central Committee plenum and then again on the final day of the Main Military Council's conference in mid-April. See "O voennoi ideologii" ([May 1940]), RGVA, f. 9, op. 36s, d. 4252, 1. 116 (published in D. L. Brandenberger, "Lozhnye ustanovki $v$ dele vospitaniia $i$ propagandy:' doklad nachal'nika Glavnogo politicheskogo upravleniia RKKA L. Z. Mekhlisa o voennoi idelogii, 1940 g.," Istoricheskii arkhiv no. 5-6 [1997]: 92, 85); V. Malyshev, "Proidet desiatok let, i eti vstrechi ne vosstanovish' uzhe v pamiati," Istochnik no. 5 (1997), 110; Zimniaia voina 1939-1940, vol. 2, Stalin i finskaia kampaniia (Stenogramma soveshchaniia pri TsK VKP(b)), E. N. Kul'kov and O. A. Rzheshevskii, eds. (Moscow 1999), 274-78; "Zapis' ukazanii tovarishcha Stalina na zasedanii Komissii Glavnogo voennogo soveta 21 aprelia 1940 goda v Kremle," RGVA, f. 4, op. 14, d. 2768, 11. 64-5; Istoriia Velikoi Otechestvennoi voiny Sovetskogo Soiuza, vol. 1, edited by P. N. Pospelov (Moscow 1960), 277; Carl Van Dyke, The Soviet Invasion of Finland, 1939-1940 (London and Portland 1997), 202.

59 M. I. Kalinin, "O kommunisticheskom vospitanii /doklad na sobranii partiinogo aktiva gor. Moskvy/' (2 October 1940), Tsentr khraneniia dokumentov molodezhnykh organizatsii (hereafter TsKhDMO), f. 1, op. 23, d. 1389, 11. 27-32; printed in M. I. Kalinin, Izbrannie proizvedeniia, vol. 3 (Moscow 1962), 396-418 (cites on pages 30-32 and $410-412$ respectively).

${ }^{60}$ Nicolas Berdyaev, The Origins of Russian Communism, translated by R. M. French (London 1937), 171-77.

61 See "Glubokouvazhaemyi Iosif Vissarionovich" (31 January 1939), RTsKhIDNI, f. 17 , op. 120 , d. 348 , 1. 63. N. K. Krupskaia expressed similar fears in a 1938 letter to Stalin which is published in Izvestiia TsK no. 3 (1989), 179. The party hierarchy responded with a Central Committee resolution scolding literatory and other contributors to official "thick journals" for their reluctance to join the patriotic campaign, something detailed in "O nekotorykh literaturno-khudozhestvennykh zhurnalakh," Bol'shevik no. 17 (1939), 51-7. Generally, see "Vse cherty rasovogo natsionalizma...": Internatsionalist zhaluetsia Stalinu (ianvar' 1939), Voprosy istorii no. 1 (2000): 128-33.

62 Nicholas Timasheff, The Great Retreat: The Growth and Decline of Communism in Russia (New York 1947), chapter 7; Frederick C. Barghoorn, Soviet Russian 
Nationalism (New York 1956), 28-34, 148-52, 233-7, 260; idem, "Four Faces of Soviet Russian Ethnocentrism," in Ethnic Russia in the USSR: the Dilemma of Dominance, Edward Allworth, ed. (New York 1980), 57; idem, "Russian Nationalism and Soviet Politics: Official and Unofficial Perspectives," in The Last Empire: Nationality and the Soviet Future, Robert Conquest, ed. (Stanford 1986), 35; Ivan Dzyuba, Internationalism or Russification: A Study of the Soviet Nationalities Problem, ed. M. Davies, (London 1968), 65; Hans Kohn, "Soviet Communism and Nationalism: Three Stages of a Historical Development," in Soviet Nationality Problems, ed. Edward Allworth, (New York 1971), 57; Evg[enii] Anisimov, "Stereotipy imperskogo myshleniia," in Istoriki otvechaiut na voprosy, 1st issue (Moscow 1990), 76-82; Zvi Gitelman, "Development and Ethnicity in the Soviet Union," in The Post Soviet Nationalities: Perspectives on the Demise of the USSR, Alexander J. Motyl, ed. (New York 1992), 223; G. Kostyrchenko, $V$ plenu u krasnogo faraona: politicheskie presledovaniia evreev $v$ SSSR v poslednee stalinskoe desiatiletie - dokumental'noe issledovanie (Moscow 1994), 7; Stephen Blank, The Sorcerer as Apprentice: Stalin as Commissar of Nationalities, 1917-1924 (London 1994), 211-25.

${ }^{63}$ Mehnert, Weltrevolution durch Weltgeschichte: die geschichtslehre des Stalinismus, $11,72-3$.

64 Roman Szporluk, "History and Russian Ethnocentrism," in Ethnic Russia in the USSR, 44-45; idem, Communism and Nationalism: Karl Marx versus Friedrich List (New York 1988), esp. 219-220; Dmitry V. Pospelovsky, "Ethnocentrism, Ethnic Tensions, and Marxism/Leninism," in Ethnic Russia in the USSR, 127; Yuri Y. Glazov, "Stalin's Legacy: Populism in Literature," in The Search for Self-Definition in Russian Literature, Ewa Thompson, ed. (Houston 1991), 93-95, 99; Robert J. Kaiser, The Geography of Nationalism in the USSR (Princeton 1994), 144; E. A. Rees, "Stalin and Russian Nationalism," in Russian Nationalism Past and Present, G. Hosking and R. Service, eds. (New York 1998), 77, 97, 101-3.

${ }^{65}$ Mehnert, Weltrevolution durch Weltgeschichte: die geschichtslehre des Stalinismus, 12-14; P. K. Urban, Smena tendentsii v sovetskoi istoriografii (Munich 1959), 9-11; John B. Dunlop, The Faces of Contemporary Russian Nationalism (Princeton 1983), 10-12; Iu. N. Amiantov, "Vstupitel'naia stat'ia: Stenogramma soveshchaniia po voprosam istorii SSSR v TsK VKP(b) v 1944 godu," Voprosy istorii no. 2 (1996), 48; S. V. Konstantinov, "Dorevoliutsionnaia istoriia Rossii v ideologii VKP(b) 30-kh gg.", in Istoricheskaia nauka Rossii v XX veke (Moscow 1997), 226-7; Ronald Grigor Suny, "Stalin and his Stalinism: Power and Authority in the Soviet Union," in Stalinism and Nazism: Dictatorships in Comparison, Ian Kershaw and Moshe Lewin, eds. (Cambridge UK 1997), 39; idem, The Soviet Experiment: Russia, the USSR and the Successor States (Oxford 1998), 252-3.

66 C. E. Black, "History and Politics in the Soviet Union," in Rewriting Russian History: Soviet Interpretations of Russia's Past (New York 1956), 24-25; Shteppa, Soviet Historians and the Soviet State, 124, 134-35; Marc Slonim, Soviet Russian Literature: Writers and Problems, 1917-1977, 2nd edition (New York 1977), 268; M. Agurskii, Ideologiia natsional-bol'shevizma (Paris 1980), 140-42; Moshe Lewin, The Making of the Soviet System: Essays in the Social History of Inter-War Russia (London 1985), 272-9; M. Heller and A. Nekrich, Utopia in Power: the History of the Soviet Union from 1917 to the Present, Phyllis Carlos, trans. (New York 1986), 269; Mikhail Agursky, "The Prospects for National Bolshevism," in The Last Empire, 90; Hugh 
Seton Watson, "Russian Nationalism in Historical Perspective," in ibid., 25, 28; Alain Besançon, "Nationalism and Bolshevism in the USSR," in ibid., 4; Tucker, Stalin in Power: The Revolution from Above, 50-8, 319-28, 479-86; V. B. Kobrin, "Pod pressom ideologii," Vestnik AN SSSR no. 12 (1990), 36-7; Gerhard Simon, Nationalismus und Nationalitätenpolitik in der Sowjetunion: Von der totalitären Diktatur zur nachstalinschen Gesellschaft (Baden-Baden 1986), 172-73; Stephen Velychenko, Shaping Identity in Eastern Europe and Russia: Soviet-Russian and Polish Accounts of Ukrainian History (New York 1993), 22; Kaiser, The Geography of Nationalism in the USSR, 145; Kostyrchenko, V plenu u krasnogo faraona: politicheskie presledovaniia evreev v SSSR v poslednee stalinskoe desiatiletie, 7-8; Suny, "Stalin and his Stalinism: Power and Authority in the Soviet Union," 39; Maureen Perrie, "Nationalism and History: the Cult of Ivan the Terrible in Stalin's Russia," in Russian Nationalism Past and Present, 107-28.

${ }^{67}$ Roman Szporluk, "Nationalities and the Russian Problem in the USSR: an Historical Outline," Journal of International Affairs, vol. 27, no. 1 (1973), 30-31; Dunlop, The Faces of Contemporary Russian Nationalism, 10-12; Martin, "An Affirmative Action Empire: Ethnicity and the Soviet State, 1923-1938," esp. chapter 10; idem, "The Russification of the RSFSR," Cahiers du Monde misse et soviétique vol. 39 (1998), 99, 112-13; Mark von Hagen, "Stalinism and the Politics of Post-Soviet History," in Stalinism and Nazism: Dictatorships in Comparison, 305; Suny, The Soviet Experiment, 289-90.

68 Harold Swayze, Political Control of Literature in the USSR, 1946-1959 (Cambridge Mass. 1962), 28; Lowell Tillet, The Great Friendship: Soviet Historians on the NonRussian Nationalities (Chapel Hill 1969), 49-61; Christel Lane, The Rites of Rulers: Ritual in Industrial Society - the Soviet Case (Cambridge 1981), 181; Alexander Werth, Russia at War, 1941-1945 (New York 1984), 120, 249-50; Vera S. Dunham, In Stalin's Time: Middleclass Values in Soviet Fiction, enlarged and updated edition (Durham and London 1990), 12, 17, 41, 66; Stephen K. Carter, Russian Nationalism: Yesterday, Today, Tomorrow (New York 1990), 51; John Barber and Mark Harrison, The Soviet Home Front, 1941-1945: A Social and Economic History of the USSR in World War II (London 1991), 69; Nina Tumarkin, The Living and the Dead: The Rise and Fall of the Cult of World War II in Russia (New York 1994), 63; Genadii Bordiugov, “Bol'sheviki i natsional'naia khorugv'," Rodina no. 5 (1995), 74; Victoria E. Bonnell, Iconography of Power: Soviet Political Posters under Lenin and Stalin (Berkeley 1997), 255-57; E. Iu. Zubkova, "Mir mnenii sovetskogo cheloveka, 1945-1948: po materialam TsK VKP(b)," Otechestvennaia istoriia no. 3 (1998), 34.

${ }^{69}$ Kotkin, Magnetic Mountain: Stalinism as a Civilization, 229-30. Kotkin seemingly contradicts himself deeper into the volume when he acknowledges the cultivation of Russian nationalist sentiments as a part of a shift from "the task of building socialism to that of defending socialism" (See page 357). Simon Dixon flatly denies the existence of a russocentric mobilization drive in his "The Past in the Present: Contemporary Russian Nationalism in Historical Perspective," in Russian Nationalism Past and Present, 158.

70 See D. L. Brandenberger and A. M. Dubrovsky, "“The People Need a Tsar': the Emergence of National Bolshevism as Stalinist Ideology, 1931-1941," Europe-Asia Studies vol. 50, no. 5 (1998), 871-90.

71 In a sense, of course, they did. Although they remained in print, virtually all the 
Proletarian Internationalism 103

classics of Socialist Realism were savaged by the censor during the period. See Herman Ermolaev, Censorship in Soviet Literature, 1917-1991 (New York 1997), 51-140. Korchagin and Chumalov, incidentally, were the heroes of Ostrovskii's How the Steel was Forged and Gladkov's Cement, respectively.

${ }^{72}$ Linda Colley makes a similar point about the political usefulness of long-dead heroes in Britons: Forging the Nation, 168-69. 